\title{
Is the G.C.E. (AL) Bio Science stream a dead end to many? An analysis of educational opportunity in the Bio Science stream
}

\author{
S. Rupasinghe' \\ The Ceylon Journal of Medical Science 2002; 45: 13-24
}

\begin{abstract}
The Biological Science (Bio Science) stream had remained very popular and competitive among the subject streams offered at the General Certificate of Education, Advanced Level, as it paves the way for admission to some of the prestigious faculties in the universities. There was a clear swing towards the Science streams during the period following the 1972 curricular reforms, through which Science and Maths came to be taught in all secondary schools that had grades up to G.C.E., OL. However the trend has changed in recent years with student numbers enrolling for Science decreasing by about 16 per cent between years 1986 and 1996. This swing away from Science had been partly attributed to the highly selective and restrictive admission policies followed by the faculties concerned in the universities, amidst an increasing demand for places.
\end{abstract}

The objective of this paper, therefore, is to analyse the trends prevailing in the Bio Science stream during the period, 1990 to 2000 . It was revealed from the study that the number eligible for admission to universities had increased during the period concerned. However, the percentage admitted had remained low despite variations from year to year. All relevant faculties-Medicine, Science, Agriculture, Veterinary Science and Dental have followed very restrictive admission policies and the percentage of admissions had remained constant despite increasing pressure during the relevant period. It was also revealed that nearly 75 per cent of eligible candidates have been annually shut off from universities. Even though a large number of females qualify for admission, the probability of a female being admitted remains at 0.23 .

The question at stake is whether faculties will

1. Professor, Faculty of Education, University of Colombo. democratize their admission to a certain extent or remain exclusive amidst the current growing demand.

\section{Introduction}

The establishment of the Ceylon Medical School in 1870 , followed by the Ceylon University College in 1921, and the subsequent amalgamation of the two institutions to form the University of Ceylon in 1942, provided the long awaited opportunity for university education in Bio Science in Ceylon. This was the much-desired breakthrough after a long period of continuous agitation for higer education. Education in Bio Science became very attractive as it paved the way for lucrative professional occupations, which were in great demand due to the recognition of these institutions in Britain.

The opportunities provided for higher education in Bio Science resulted in doctors being the most sought after profession. This fact is supported by a resume of several studies on occupational aspirations of secondary school students, spanning a period of about 50 years - Green T.L. (1952), Jayasuriya J.E. (1961), Muthulingam S. (1973) Jayaweera S. (1973 and 1976), Wansinghe J. (1982), Rupasinghe S. (1990) and Jayaweera S. and Rupasinghe S. (1998). Doctor and engineer occupied the top ranks until about the 1970s. Since then the aspirations of secondary school students have taken a slight turn with professions like teacher, nurse and accountant emerging as popular career options and at present, teaching and nursing appear to be close preferences along with medicine for future careers, specially among female students. Table 1 gives a summary of vocational aspirations of students according to major research studies conducted during the period 1952 to 1998. 
Table 1

Vocational aspirations of secondary school students - Ranks of major occupations according to research studies (1952-1998)

\begin{tabular}{|c|c|c|c|c|c|c|c|c|c|c|c|c|c|c|}
\hline Researcher & \multirow{2}{*}{\multicolumn{2}{|c|}{$\begin{array}{c}\text { Green } \\
1952 \\
\end{array}$}} & \multirow{4}{*}{\begin{tabular}{c|} 
Jayasuriya \\
1961 \\
OL high IQ
\end{tabular}} & \multirow{4}{*}{\begin{tabular}{|c|} 
Muthulingam \\
\\
Age \\
$15-17$ \\
\end{tabular}} & \multicolumn{2}{|c|}{ Jayaweera } & \multirow{2}{*}{\multicolumn{2}{|c|}{$\begin{array}{c}\text { Wanasinghe } \\
1982 \\
\end{array}$}} & \multirow{2}{*}{\multicolumn{4}{|c|}{ Rupasinghe }} & \multirow{2}{*}{\multicolumn{2}{|c|}{$\begin{array}{c}\begin{array}{r}\text { Jayaweera \& } \\
\text { Rupasinghe }\end{array} \\
1998\end{array}$}} \\
\hline Year & & & & & 1973 & 1976 & & & & & & & & \\
\hline Sample & \multicolumn{2}{|c|}{ SSC } & & & \multicolumn{2}{|c|}{$\mathrm{OL}$} & \multicolumn{2}{|c|}{ Science } & \multicolumn{2}{|c|}{$\mathrm{OL}$} & \multicolumn{2}{|c|}{$\mathrm{AL}$} & \multicolumn{2}{|c|}{ OL } \\
\hline Gender & M & $\mathrm{F}$ & & & $\mathrm{F}$ & $\mathbf{F}$ & $\mathbf{M}$ & $F$ & $\mathrm{~T}$ & $\mathbf{F}$ & $\mathbf{T}$ & $\mathbf{F}$ & $\mathbf{T}$ & $F$ \\
\hline$\frac{\text { Occupation }}{\text { Doctor }}$ & 1 & 1 & 2 & 1 & 2 & 1 & 2 & 1 & 2 & 2 & 1 & 2 & 2 & 3 \\
\hline Engineer & 2 & 3 & 1 & 4 & 8 & 5 & 1 & 5 & 3 & 7 & 4 & 6 & 5 & 6 \\
\hline Teacher & 3 & 2 & 3 & 6 & 1 & 2 & 6 & 2 & 1 & 1 & 2 & 1 & 1 & 1 \\
\hline Accountant & - & - & - & - & 6 & 8 & - & - & 4 & 5 & 3 & 4 & 9 & 9 \\
\hline Nurse & - & - & - & - & 3 & 3 & - & - & 6 & 3 & - & - & 4 & 2 \\
\hline Clerk & - & - & - & - & 4 & 6 & 4 & 3 & 5 & 4 & 5 & 3 & 8 & 5 \\
\hline $\begin{array}{l}\text { Police } \\
\text { Inspector }\end{array}$ & 6 & 7 & - & 8 & 10 & 7 & - & - & - & - & - & - & 7 & 4 \\
\hline
\end{tabular}


Despite the slight shift in vocational aspirations of students, the Bio Science stream at the upper secondary level in schools, even today, attracts a considerable number of students in areas where opportunity for G.C.E (AL) Science is available. This can be attributed to the fact that Bio Science stream leads the way to enter the Faculties of Medicine in the national universities.

Related to the above discussion, changes have aiso occurred in enrolment at the G.C.E. (AL) and a distinct shift away from the Science stream has taken place at the secondary school level in recent years. Table 2 below depicts the situation.

School Census data in Table 2 reveals that there had been a gradual swing towards Science up to 1986, mainly attributed to the Curriculum Reforms of 1972 by which steps were taken to teach
Science and Maths oriented courses. But after 1986 a gradual shrinking of the Science stream had taken place at the Advanced Level up to year 2000 , after which a slight positive change is witnessed.

It is pertinent to find out the reasons for this swing away from Science. Discussions with Science teachers from secondary schools reveals that this is due to the frustration the students undergo in the Bio Science stream by failing to get admission to Science-based courses in universities, particularly Medicine.

The objective of this paper, therefore, is to analyze the prevailing situation in the Bio Science stream regarding opportunity for admission to national universities and highlight the changes that have taken place in secondary school enrolment for Science over the period 1990-2000.

Table 2

Enrolment in G.C.E. (AL) Streams (1981-2000) Percentages

\begin{tabular}{|l|c|c|c|c|c|c|c|}
\hline $\begin{array}{l}\text { Subject } \\
\text { Stream : }\end{array}$ & 1981 & 1986 & 1989 & 1992 & 1996 & 1997 & 2000 \\
\hline Science & 30.4 & 37.0 & 31.0 & 25.6 & 21.1 & 21.1 & 22.6 \\
\hline Arts & 39.2 & 37.6 & 42.5 & 45.0 & 50.8 & 52.6 & 49.4 \\
\hline Commerce & 30.4 & 25.4 & 26.5 & 29.4 & 28.1 & 26.2 & 28.0 \\
\hline $\begin{array}{c}\text { Total } \\
\text { Cotal } \\
\begin{array}{c}\text { Atudent } \\
\text { enrolment } \\
\text { in } \\
\text { thousands }\end{array}\end{array}$ & 100.0 & 100.0 & 100.0 & 100.0 & 100.0 & 100.0 & 100.0 \\
\hline
\end{tabular}

Source: School Census Reports, Ministry of Education 
16

\section{Methods}

The collection of data for this study was carried out mainly by using document analysis. List of documents perused are given below.

- School census reports of the Ministry of Education.

- Statistical hand books of the University Grants Commission.

- Research reports of the Centre for Women's Research.

- Statistical hand books of the Department of Examinations.

\section{Opportunity for admission to Science based faculties from the Bio Science stream}

Table 3 gives the total number of G.C.E. AL students qualifying for University admission during the period 1990 to 2000 with numbers qualifying from Bio and Physical Science streams worked out as percentages, calculated out of the total number qualifying. The data in Table 3 shows that more students have qualified from the Bio stream compared with the Physical Science stream over the entire period concerned. For instance, $13.5 \%$ more students have qualified from the Bio stream in relation to the Physical Science stream in 1990 , and the figure had fluctuated between 12.6 and $8.8 \%$ during the subsequent years. The difference stands at $8.5 \%$ in 2000 . Meanwhile over the same period the percentages qualifying in both streams had decreased, by $7.1 \%$ in the Bio stream compared to the $2.1 \%$ in the Pilysical Science stream. Two trends in the number of students qualifying from AL Bio Science stream for university admission can be recognized as given below:

1. The actual number qualifying had increased over the decade under review from 7985 to 10,470 , but this number as a percentage of the total number qualifying for university admission has declined to $14.2 \%$ in year 2000 from $21.3 \%$ in 1990 .

2. The number qualifying in Bio Science has been considerably higher than the number qualifying in Physical Science - a difference of approximately 6215 in 2000 compared to 5068 in 1990.

\section{S. Rupusinghte}

A comparison with the Arts stream reveals that in Arts both the number qualifying and percentages have increased dramatically over the same period. The number had risen by 25831 while the percentage had swelled to $56.4 \%$ in year 2000 from $42.8 \%$ in 1990 . The comparative increase in the number for Bio Science had been only 2485.

Table 4, depicts the position from another aspect - i.e. the percentage of students admitted out of the qualified number of students in the Bio Science stream with comparable figures for the Physical Sciences. From the data it is quite clear that in the Bio Science stream only around $27 \%$ could get into a University while $73 \%$ had been turned down in year 2000 . Number qualifying and number admitted to the University has fluctuated, but has left or shut out around 7600-8200 students annually during the last four years. This figure appears to be high when compared with the Physical Science stream where the percentage of admissions have remained steady over the last four years and stands at $61.6 \%$ in 2000 leaving out only $38.4 \%$ 1600 students.

The difference in opportunity for admission to a university between Bio and Physical streams remain very distinct. Bio Science has offered less opportunity for a large number who have qualified and who have demanded a place in a university. This has been the case specially regarding the field of Medicine, the aspiration of many students who select the Bio stream.

Table 5 gives the distribution of students who had been admitted from AL Bio Science to the different Faculties in the universities. The figures are given as numbers and percentages calculated from the total number who had qualified from Bio Science in the relevant years.

A perusal of Table 5 indicates that the Medical Faculties, the most sought after, admits only 881 students or $8.4 \%$ of the 10,470 students who have qualified in 2000 . The figure approximately corresponds to $31 \%$ of the $\mathbf{2 8 3 5}$ admitted for the same year. Over the period concerned, the Medical Faculties of the universities have confined their admission to between 7.4 and $11.1 \%$ out of the total number qualifying.

The Ceylon Journal of Medical Science 
Table 3

\begin{tabular}{|c|c|c|c|c|c|c|c|c|}
\hline G.C.E. (AL) & \multirow{2}{*}{$\begin{array}{c}\text { Academic } \\
\text { Year }\end{array}$} & \multirow{2}{*}{$\begin{array}{c}\text { Total Number } \\
\text { Qualifying } \\
\text { from AL }\end{array}$} & \multicolumn{2}{|c|}{ Qualifying in Bio Science } & \multicolumn{2}{|c|}{ Qualifying in Physical Science } & \multicolumn{2}{|c|}{ Qualifying in Arts } \\
\hline & & & Number & Percentage & Number & Percentage & Number & Percentage \\
\hline 1999 & $2000-01$ & 73,561 & 10,470 & 14.2 & 4225 & 5.7 & 41845 & 56.4 \\
\hline 1998 & 1999-00 & 73,442 & 12,088 & 16.4 & 3905 & 5.3 & 43119 & 58.7 \\
\hline 1997 & $1998-99$ & 73,570 & 11,132 & 15.1 & 3526 & 4.8 & 39147 & 53.2 \\
\hline 1995 & $1996-97$ & 70,382 & 11,081 . & 15.7 & 3916 & 5.6 & 34582 & 49.1 \\
\hline 1994 & $1995-96$ & $56,70.3$ & 10,516 & 18.5 & 3609 & 6.0 & 25484 & 44.9 \\
\hline 1993 & $1994-95$ & 59,292 & 12,508 & 21.0 & 5018 & 8.4 & 25828 & 43.6 \\
\hline 1992 & $1993-94$ & 55,144 & 8,914 & 16.2 & 3795 & 6.8 & 25464 & 46.2 \\
\hline 1991 & $1992-93$ & 50,362 & 8,076 & 16.0 & 4472 & 8.8 & 21078 & 41.8 \\
\hline 1990 & $1991-92$ & 42,454 & 7,916 & 18.6 & 3349 & 7.8 & 19008 & 44.7 \\
\hline 1989 & $1990-91$ & 37,354 & 7,985 & 21.3 & 2917 & 7.8 & 16014 & 42.8 \\
\hline
\end{tabular}

Source: University Statistical Hand Books, University Grants Commission Data for 1996 not included. 
Table 4

Admissions in the Bio Science - Qualified Vs Admitted

\begin{tabular}{|c|c|c|c|c|}
\hline Academic year & $\begin{array}{l}\text { No. qualifying } \\
\text { for Bio Science }\end{array}$ & No. Admitted & $\begin{array}{l}\text { Percentage } \\
\text { admitted }\end{array}$ & $\begin{array}{l}\text { Comparable } \\
\text { percentage for } \\
\text { Physical Science }\end{array}$ \\
\hline $2000-2001$ & 10,470 & 2835 & 27.0 & 61.6 \\
\hline $1999-2000$ & 12,088 & 2766 & 22.8 & 67.2 \\
\hline $1998-1999$ & 11,132 & 2862 & 25.7 & 69.8 \\
\hline $1996-1997$ & 11,081 & 2790 & 25.1 & 59.4 \\
\hline $1995-1996$ & 10,516 & 2176 & 20.6 & 56.8 \\
\hline $1994-1995$ & 12,508 & 2041 & 16.3 & 40.2 \\
\hline $1993-1994$ & 8,914 & 1923 & 21.5 & 48.1 \\
\hline $1992-1993$ & 8,076 & 1944 & 24.0 & 39.9 \\
\hline $1991-1992$ & 7,916 & 2373 & 29.9 & 61.2 \\
\hline $1990-1991$ & 7,985 & 2501 & 31.3 & 68.0 \\
\hline
\end{tabular}

Source: University Statistical Hand Books, University Grants Commission Data for 1997-1998 not included.

Table 5

Admissions in the different faculties from the Bio Stream: number and percentage out of those qualifying from AL Bio Science

\begin{tabular}{|c|c|c|c|c|c|c|c|c|}
\hline \multirow{2}{*}{$\begin{array}{l}\text { Academic } \\
\text { year }\end{array}$} & \multicolumn{2}{|c|}{ Medicine } & \multicolumn{2}{|c|}{ Agriculture } & \multicolumn{2}{|c|}{ Biology } & \multirow{2}{*}{$\begin{array}{c}\text { Dental } \\
\mathbf{n} \\
\end{array}$} & \multirow{2}{*}{$\begin{array}{c}\text { Vet } \\
\% \\
\end{array}$} \\
\hline & $\mathbf{n}$ & $\%$ & $\mathbf{n}$ & $\%$ & $\mathbf{n}$ & $\%$ & & \\
\hline $2000-2001$ & 881 & 8.4 & 721. & 6.8 & 1070 & 10.2 &. .163 & 1.5 \\
\hline $1999-2000$ & 896 & 7.4 & 646 & 5.3 & 1042 & 8.6 & 182 & 1.5 \\
\hline 1998-1999 & 893 & 8.0 & 670 & 6.0 & 1139 & 10.2 & 160 & 1.4 \\
\hline 1997-1998 & 867 & - & 684 & - & 765 & - & 178 & - \\
\hline $1996-1997$ & 859 & 7.7 & 673 & 6.0 & 867 & 7.8 & 169 & 1.5 \\
\hline 1995-1996 & 877 & 8.3 & 273 & 2.5 & 880 & 8.3 & 146 & 1.3 \\
\hline 1994-1995 & 863 & 6.8 & 269 & 2.1 & 768 & 6.1 & 135 & 1.6 \\
\hline $1993-1994$ & 769 & 8.6 & 335 & 3.8 & 678 & 7.6 & 141 & 1.5 \\
\hline $1992-1993$ & 791 & 9.8 & 325 & 4.0 & 686 & 8.5 & 142 & 1.7 \\
\hline 1991-1992 & 882 & 11.1 & 396 & 5.0 & 911 & 11.5 & 184 & 2.3 \\
\hline $1990-1991$ & 860 & 10.7 & 479 & 5.9 & 983 & 12.3 & 179 & 2.2 \\
\hline
\end{tabular}

Source: University Statistical Hand Books, University Grants Commission $\mathrm{n}=$ number of students 

opportunity in the Bio Science stream

Bio Science offers a little more places (10.2\%), while Agriculture (6.8\%) and Dental and Vet (1.5\%) fall behind Medicine. Even though the percentages fluctuate the patterns remains the same.

\section{Gender difference in admissions}

Table 6 depicts the situation regarding female students. Here again the greater percentage who qualify in Bio Science appear to be female approximately $59.2 \%$ of the total qualifying in 2000 , but when the admitted category is taken into consideration a fewer number of females get into the universities, the figure being $24.3 \%$ of the females who have qualified. On the other hand even though a lesser number of males qualify, their percentage of admission appears to be higher than that of girls. This in other words conveys that a large number of females, compared to males are shut out from the University despite the fact that more females qualify for admission.

This situation was earlier analysed by Indraratne and Kotahachchi (1993) by examining admissions during the period 1981-82 to 1990-91 and attributed it to the differences in achievement between males and temales - the raw aggregate marks scored by the two groups. During the period concerned, out of the qualified, $29.18 \%$ of the males had entered, and they concluded that even though a larger number of females qualify by achieving the minimum mark, they fail to get admission due to their inability to clear the cut off point.

Jayaweera and Rupasinghe (1996) explored this situation further by examining the UGC data for $1993-1994$ admissions. Here the admissions were calculated taking into consideration the number applying for admission instead of the number qualifying and the data is presented in Table 7.

Table 6

Numbers of females and males admitted out of those qualifying

\begin{tabular}{|l|l|l|c|c|c|c|}
\hline $\begin{array}{l}\text { Academic } \\
\text { year }\end{array}$ & $\begin{array}{l}\text { Total } \\
\text { qualifying } \\
\text { Bio Science }\end{array}$ & $\begin{array}{l}\text { Females } \\
\text { qualifying }\end{array}$ & $\begin{array}{c}\% \\
\text { of females } \\
\text { qualifying }\end{array}$ & $\begin{array}{l}\text { Females } \\
\text { admitted }\end{array}$ & $\begin{array}{c}\% \\
\text { of females } \\
\text { admitted }\end{array}$ & $\begin{array}{c}\% \\
\text { of males } \\
\text { admitted }\end{array}$ \\
\hline $2000-2001$ & 10,470 & 6199 & 59.2 & 1509 & 24.3 & 31.0 \\
\hline $1999-2000$ & 12,088 & 7081 & 58.6 & 1461 & 20.6 & 26.0 \\
\hline $1998-1999$ & 11,132 & 6499 & 58.3 & 1501 & 23.1 & 29.4 \\
\hline $1996-1997$ & 11,081 & 6259 & 56.4 & 1383 & 22.1 & 29.2 \\
\hline $1995-1996$ & 10,516 & 5903 & 56.1 & 1001 & 16.9 & 25.4 \\
\hline $1994-1995$ & 12,508 & 7275 & 58.1 & 1020 & 14.0 & 19.5 \\
\hline $1993-1994$ & 8,914 & 4863 & 54.6 & 842 & 17.3 & 21.5 \\
\hline $1992-1993$ & 8,076 & 4412 & 54.6 & 894 & 20.2 & 24.0 \\
\hline $1991-1992$ & 7,916 & 4443 & 56.1 & 1195 & 26.9 & 29.9 \\
\hline $1990-1991$ & 7,985 & 4374 & 54.6 & 1241 & 28.3 & 31.3 \\
\hline
\end{tabular}

Source: University Statistical Hand Books, University Grants Commission

Column 6 - Percentage of females admitted out of total number of females qualifying

Column 7 - Percentage of males admitted out of total number of males qualifying

Data for 1997-1998 not included. 
Table 7

1993-1994 Admissions - Bio Science

\begin{tabular}{|l|c|c|c|}
\hline Gender & $\begin{array}{c}\text { Number } \\
\text { applying }\end{array}$ & $\begin{array}{l}\text { Number } \\
\text { admitted }\end{array}$ & $\begin{array}{l}\text { Percentage } \\
\text { admitted }\end{array}$ \\
\hline Male & 2139 & 1331 & 62.23 \\
\hline Female & 2399 & 1103 & 45.97 \\
\hline Total & 4538 & 2434 & 53.66 \\
\hline
\end{tabular}

Source: University Grants Commission Admissions Data Records

The researchers attributed this difference to the raw aggregate marks scored by the two groups, which in turn is a direct result of their performance in the subjects.

The percentage of A and B grades scored by the males amd females in the five subjects are given in Table 8.

Jayaweera and Rupasinghe also analysed the distribution of aggregate marks of students who failed to get selected in 1993-1994. The data is given in Table 9.

Out of the 2104 who failed to get admitted among applicants (Table 9) $61.6 \%$ were female and their overall performance in terms of the raw aggregate mark was poor.

\section{Impact of the District Quota System on merit}

It would be pertinent at this point to examine the impact the District Quota System (operative since 1974) on admissions to universities with reference to the Bio Science stream.

During the admission year 1993-94 the original cut off mark for Medicine from the Colombo District before vacancies were filled had been 271 while it was 210 for Moneragala. Accordingly 189 students were selected from Colombo District while only 12 students were selected from Moneragala for Faculties of Medicine in the universities. Within the gap of 61 marks between the two cut off points for Moneragala and Colombo (range between 210 and 271) there ivere 662 eligible candidates in the Colombo District who would not be considered for selection for Medicine. Out of this 359 or $54.2 \%$ were female Such situations very often resulted in frustration among students, who were aspiring to join the Faculties of Medicine, as well as their parents.

During the same academic year the cut off mark for Jaffna in Medicine had been 266 and this left out 247 students in Jaffna District who would not be selected for Medicine but had scored an aggregate mark of over 210, the cut off mark for Moneragala.

Similarly between the cut off mark for Colombo and Jaffna (271 and 266 respectively) there were 42 students in the Colombo District who had surpassed Jaffna cut off point but remained below the Colombo cut off point.

However, with a cut off mark as low as 210 , Moneragala could send only 12 students to the Medical Faculty compared with 201 from Colombo and 41 from Jaffna (UGC Hand Book 1995).

A status similar to Colombo and Jaffna exists in other high achieving and heavily populated districts also. For instance, in 1993-94, 229 students from Kandy, 222 from Galle, 293 from Matara and 184 from Gampaha could not get themselves considered for selection despite their high aggregate marks. This really diminishes the hopes of even high achievers in the Bio Science stream.

\section{Situation at collegiate level}

The significant changes that had occurred in the enrolment for Science at G.C.E. (AL) between 1991 and 2001 is given in detail, district by district, in Table 10. From 1991 to 1997, except for the districts of Mannar, Trincomalee and Moneragala, all the other districts had undergone negative changes in the percentages enrolled for Science, out of the total enrolments for $A L$ in each district. In contrast between 1997 and 2000 all districts 
Table 8

A and B Grades scored by students selected for admissions, Bio Science Stream - 1993-1994

\begin{tabular}{|l|c|c|c|}
\hline \multirow{2}{*}{ Subject } & \multicolumn{3}{|c|}{ Percentage of A and B grades } \\
\cline { 2 - 4 } & Male & Female & \% Gender Difference (M - F) \\
\hline Physics & 28.84 & 16.88 & +12.0 \\
\hline Zoology & 19.09 & 16.77 & +2.32 \\
\hline Chemistry & 57.62 & 58.39 & -00.77 \\
\hline Botany & 63.79 & 71.08 & -7.29 \\
\hline Agriculture & 90.62 & 76.39 & +14.23 \\
\hline
\end{tabular}

Source: University Grants Commission data records $\quad \mathrm{M}=$ Male; F=Female

Table 9

Distribution of aggregate marks according to gender of students who were not selected

\begin{tabular}{|l|c|c|c|c|c|c|}
\hline \multirow{2}{*}{$\begin{array}{l}\text { Aggregate } \\
\text { marks }\end{array}$} & \multicolumn{2}{|c|}{ Male } & \multicolumn{2}{c|}{ Female } & \multicolumn{2}{c|}{ Total } \\
\cline { 2 - 7 } & Number & $\%$ & Number & $\%$ & Number & $\%$ \\
\hline $240-243$ & 31 & 42.5 & 42 & 57.5 & 73 & 100.0 \\
$220-239$ & 335 & 39.4 & 516 & 60.6 & 851 & 100.0 \\
$200-219$ & 268 & 37.3 & 451 & 62.7 & 719 & 100.0 \\
$180-199$ & 174 & 37.7 & 287 & 62.3 & 461 & 100.0 \\
Total & 808 & 38.4 & 1296 & 61.6 & 2104 & 100.0 \\
\hline
\end{tabular}

Source: University Grants Commission Admission data records 
Table 10

Enrolment in the Science stream as a percentage of the total enrolment at $\mathrm{AL}$ in each district - percentages

\begin{tabular}{|c|c|c|c|c|}
\hline District & 1991 & & $1997^{\circ}$ & 2000 \\
\hline Colombo & 38.6 & & 33.0 & 35.5 \\
\hline Gampaha & 30.1 & & 21.4 & 23.6 \\
\hline Kalutara & 28.5 & & 21.8 & 22.1 \\
\hline Kandy & 27.2 & & 21.8 & 22.1 \\
\hline Matale & 19.6 & & 17.6 & 16.8 \\
\hline Nuwara Eliya & 17.5 & & .12 .4 & 13.1 \\
\hline Galle & $28 . \dot{5}$ & & 27.0 & 27.0 \\
\hline Matara & 24.5 & & 20.3 & 25.1 \\
\hline Hambantota & 27.0 & & 19.8 & 25.4 \\
\hline Jaffna & 33.3 & & 24.6 & 24.8 \\
\hline Mannar & 15.3 & & 16.5 & 42.5 \\
\hline Batticaloa & 22.5 & & 20.3 & 21.5 \\
\hline Ampara & 26.4 & & 20.8 & 20.9 \\
\hline Trincomalee & 18.0 & & 19.2 & 16.1 \\
\hline Kurunegala & 20.0 & & 15.5 & 18.4 \\
\hline Puttalam & 22.6 & & 16.3 & 19.4 \\
\hline Anuradhapura & 22.0 & & 17.0 & 19.1 \\
\hline Polonnaruwa & 16.8 & & 14.7 & 14.6 \\
\hline Badulla & 23.5 & · & 14.6 & 17.5 \\
\hline Moneragala & 14.2 & & 14.7 & 14.7 \\
\hline Ratnapura & 23.3 & & 17.2 & 18.5 \\
\hline Kegalle & 23.6 & & 18.7 & 20.7 \\
\hline Sri Lanka & 26.6 & & 21.2 & 22.5 \\
\hline Student Numbers & 1991 & 1997 & 2000 & \\
\hline Grade/Year 12 & 19,466 & 20224 & 51558 & \\
\hline Grade/Year 13 & & 15617 & 23754 & \\
\hline Grade/Year 13 Repeat & 30257 & 12378 & 15174 & \\
\hline Sri Lanka & 46723 & 48219 & 90786 & \\
\hline
\end{tabular}

Source: School Census Reports - Ministry of Education 
except Matale, Galle, Trincomalee, Polonnaruwa and Moneragala have recorded positive changes.

Student numbers given at the bottom of the Table shows that grade 12 Science enrolment has swelled from 20,224 in 1997 to 51,858 in 2000 , an increase of 31634 which is a $150 \%$ increase. These students are expected to sit the G.C.E AL in 2002 April. The total AL Science student increase from 1997 to 2000 has been 42,567 , an $88 \%$ increase over the period. The sudden increase in student enrolment numbers will exert additional pressure on university admissions by generating more competition for the limited number of places available in the Science oriented faculties.

A gender wise breakdown of G.C.E. (AL) Science enrolment reveals that at grade $12,47.5 \%$ are females and out of the total AL Science enrolment $46.7 \%$ are females $(42,430$ out of 90,786$)$.

This phenomenal increase in enrolment between 1997 and 2000 may be attributed to two factors: (1) the gradually increasing percentage qualifying for AL from OL. Among school candidates, only $19.4 \%$ qualified in 1995 where as in 1998 the percentage increased to $37.4 \%$ (2). The enrolment cf a double batch for grade 12 in 2000 in ozder to meet new University Academic Year Calendar dates.

\section{Conclusions}

The review of data presented in the preceding sections leads us to the following conclusions.

1. Within the Science stream at collegiate level a large number of students qualify for admission in Bio Science. In recent years approximately around $14-15 \%$ of the total number of students qualifying (all streams) belonged to the Bio Science stream. Numerically their strength had been between 10,000 and 12,000 .

2. In each cohort of students seeking admission to universities in Bio Science annually, around
$75 \%$ of them had been shut out due to nonavailability of places in university faculties. Numerically this had been about 7000 to 8000 students. Therefore the probability of a Bio Science student getting selected to the university, based on figures for the last three academic years, is 0.25 , compared to Physical Science, which is 0.66 .

3. All five University Faculties that are taking in students from Bio Science have followed very restrictive policies in the admission of students. During the last three academic years Medicine has restricted itself to $8 \%$. Science $9.6 \%$, Agriculture $6 \%$ and Vet \& Dental $1.5 \%$ of the total qualifying in the Bio Science stream.

4. Even though, a large percentage of female students qualify for admission in Bio Science, their chances of getting into a University Faculty of their choice is very slim. The probability of qualifying for females is 0.59 , but the probability of getting admitted is 0.23 . Previous research on this aspect also confirms the current situation.

5. The District Quota System which was introduced in 1974, as a measure of social justice in compensating for the obvious regional disparities in education, especially Science, also acts as a barrier for some of the high achieving students in more developed and populated districts. If the District Quota System is abolished, chances that students from areas such as Moneragala will have, to enter the University, will be meagre.

6. The sudden upward trend in the enrolment of students at collegiate level in recent years will definitely have a bearing on university admissions. If the universities fail to democratise, their admission policies or explore alternative and diversified opportunities, the situation could generate more competition resulting in frustration among a large student population for whom the doors of the universities will remain closed. 
7. Finally, considering the above facts it would be pertinent to raise the question - will the G.C.E. AL Bio Science stream lead the majority of the students along a blind alley? Will it be a dead end for a large number of students who aspire to join the most prestigious taculties of national universities?

\section{References}

1. Green T.L. Educational and social needs in Ceylon. University of Ceylon Review 1952; 10: 297-316.

2. Jayasuriya J.E. A study of vocational ambitions. Journal of the National Education Society of Ceylon 1961; 10: 1-11.

3. Muthulingam S. Factors associated with vocational choices of adolescents in Sri Lanka. Journal of the National Education Society of Sri Lanka 1973; 21: 1-36.

4. Jayaweera S. Vocational preferences of secondary school girls in Sri Lanka. Modern Ceylon Studies 1976; 7: 207-238.

5. Wanasinghe J. An investigation of the swing from Arts to Science in Sri Lanka. Sri Lanka Journal of Social Sciences, National Resources, Energy and Science Authority of Sri Lanka 1982; 5: 53-73.

6. Rupasinghe S. Students pereception of their educational needs. Sri Lanka Journal of
Social Sciences. Natural Resources, Energy and Science Authority of Sri Lanka 1988; 11: 115-136.

7. Jayaweera S., Rupasinghe S. Gender differences in vocational aspirations of secondary school students. Research paper presented at $6^{\text {th }}$ National Convention; Centre for Women's Research 1998 March.

8. School Census Data Reports 1991 to 2000 Ministry of Education.

9. University Statistical Hand Books 1994 to 2000 University Grants Commission.

10. Indraratna A.V.D. de S., Kotahachchi B.D. Gender disparities in University admissions, U.G.C. (unpublished) 1993.

11. Jayaweera S., Rupasinghe S. Gender dimensions in access to higher education; research paper presented at $5^{\text {th }}$ National Convention; Centre for Women's Research 1996 March.

12. University Grants Commission (1993-94) Admission Data Records.

13. Rupasinghe $\mathrm{S}$. University admissions in Sri Lanka: the dilemma between merit and social justice. Developments in Education; $25^{\text {th }}$ Anniversary Publication of the Faculty of Education, 2000: 48-62.

14. G.C.E. OL Examinations, Statistical Hand

$\therefore$ Book. Research and Development Branch, Department of Examinations 1999. 